\title{
Aerosol tracer testing in Boeing 767 and 777 aircraft to simulate exposure potential of infectious aerosol such as SARS-CoV-2
}

Sean M Kinahan ${ }^{1,2}{ }_{1}{ }^{*}$, David B Silcott ${ }_{1}{ }^{3}$, Blake E Silcott ${ }^{3}$, Ryan M Silcott ${ }^{3}$, Peter J Silcott $^{3}$, Braden $^{2}$ J Silcott ${ }^{3}$, Steven L Distelhorst ${ }^{2}$, Vicki L Herrera ${ }^{1}$, Danielle N Rivera ${ }^{2}$, Kevin K Crown ${ }^{2}$, Gabriel A Lucero $^{2}$, Joshua L Santarpia ${ }^{1,2}$

${ }^{*}$ Corresponding Author. Email to: skinahan@nsri.nebraskaresearch.gov;

${ }^{1}$ University of Nebraska Medical Center, 42nd and, Emile St, Omaha, NE 68198

${ }^{2}$ National Strategic Research Center, 6825 Pine Street, Omaha, NE 68106

${ }^{3}$ S3I LLC, 1135 Saffell Rd Reisterstown, MD 21136

${ }_{1}$ These authors contributed equally to this manuscript.

\begin{abstract}
The COVID-19 pandemic has reintroduced questions regarding the potential risk of SARS-CoV-2 exposure amongst passengers on an aircraft. Quantifying risk with computational fluid dynamics models or contact tracing methods alone is challenging, as experimental results for inflight biological aerosols is lacking. Using fluorescent aerosol tracers and real time optical sensors, coupled with DNA-tagged tracers for aerosol deposition, we executed ground and inflight testing on Boeing 767 and 777 airframes.
\end{abstract}

Analysis here represents tracer particles released from a simulated infected passenger, in multiple rows and seats, to determine the exposure risk via penetration into breathing zones in that row and numerous rows ahead and behind the index case. We completed over 65 releases of 180,000,000 fluorescent particles from the source, with 40+ Instantaneous Biological Analyzer and Collector sensors placed in passenger breathing zones for real-time measurement of simulated virus particle penetration.

Results from both airframes showed a minimum reduction of $99.54 \%$ of $1 \mu \mathrm{m}$ aerosols from the index source to the breathing zone of a typical passenger seated directly next to the source. An average 99.97 to $99.98 \%$ reduction was measured for the breathing zones tested in the 767 and 777 , respectively. Contamination of surfaces from aerosol sources was minimal, and DNA-tagged $3 \mu \mathrm{m}$ tracer aerosol collection techniques agreed with fluorescent methodologies. 
medRxiv preprint doi: https://doi.org/10.1101/2021.01.11.21249626; this version posted January $13,2021$. The copyright holder for this preprint

(which was not certified by peer review) is the author/funder, who has granted medRxiv a license to display the preprint in perpetuity.

It is made available under a CC-BY-NC 4.0 International license .

\section{Introduction}

The current COVID-19 outbreak caused by the SARS-CoV 2 coronavirus reintroduces questions regarding transmission risk during travel; as countries, companies, and individuals reduced travel to contain the outbreak and reduce exposure. In the US, the Transportation Security Administration (TSA) screened over $70 \%$ fewer travelers during most summer months of 2020 than a year earlier (1). The CDC has determined that airborne transmission of SARS-CoV-2 can occur in environments which include enclosed spaces, prolonged exposure, and inadequate ventilation (1), which raises questions as to prolonged contact in an aircraft cabin environment. While large-droplet transmission likely does not vary substantially from the unique circumstance of being on an aircraft, the aerosol exposure route is dependent on the ventilation, environment and exposure time. A variety of research supports this conclusion, including sampling infectious virus in the air $(3,4)$, and case studies suggesting aerosol transmission $(5,6,7)$. An example of the latter occurred in a poorly ventilated nursing home unit where $81 \%$ of patients and $50 \%$ of staff became infected. The unit was equipped with an energy-efficient HVAC unit which only introduced fresh air when $\mathrm{CO}_{2}$ levels climbed (7).

Quantifying the risk of inflight transmission is important for fully engaging economies, tourism, and business travel with human-to-human interactions. Since the exposure dose of any contaminant is a combination of the concentration and the length of time of exposure, it is important to understand both how quickly contaminants are removed, and what percentage of material penetrates the breathing zone of passengers. Existing strategies to evaluate pathogen risk on airlines include numerical models, such as computational fluid dynamics, and epidemiological studies of known-infected travelers and risk analysis.

Experimental data in these unique circumstances is challenging, in part due to challenges with methodology and instrumentation, and is largely completed in shorter cabin mockups. Tracer gases, such as sulfur hexafluoride $\left(\mathrm{SF}_{6}\right)$ or $\mathrm{CO}_{2}$, have been used to determine airflow, with implications for airflow, gaseous contaminants, and small particulates that may more easily follow air streamlines (8-10). Particle Image Velocimetry (PIV), stereoscopic PIV and volumetric particle tracking velocimetry (PVTV) have been used to examine both particle fate and visualization to help validate CFD models $(8,11-14)$.

Bennet, et al., examined bacterial dispersion in an aircraft mockup, using a Lactobacilli spray bottle, and found a near-field and far-field cutoff that likely correlates to large and small-droplets, that follow a projectile pathway or become aerosols, respectively (15). Li, et. al., utilized a combination of SF- 6 and $3 \mu \mathrm{m}$ low-volatility droplets for particle tracing in a retired MD-82 aircraft, and found agreement for $3 \mu \mathrm{m}$ and below particulate with a gaseous tracer, with a rapid drop to nearby seats, and limited but varied longitudinal spread, that is forward or aft in the plane (16). Longitudinal spread of contaminant was dependent on which tracer was utilized and where it was released. Overall, experimental data typically compares concentrations relative to other locations in the airframe or cabin mockup, with the source and quantity of contamination not characterized.

Epidemiological studies include survey and interview follow-ups for confirmed cases of both SARS-CoV-1 and SARS-CoV-2 in air transport. During the SARS-CoV-1 outbreak dthere was a series of three flights with infected passengers examined by Olsen, et al. (17). One flight, 3 hours from Hong Kong to Beijing was indicative of transmission and resulted in 22 secondary cases from a single primary case. The other two flights, 90 minutes each, had a combined single possible transmission (17).

Studies from the ongoing COVID-19 pandemic indicate varied but generally less transmission during air travel. In one study, no secondary cases were traced on a 350-person 15-hour flight from Guangzhou, China to Toronto, Canada, which included a symptomatic (coughing), PCRpositive patient, and his wife, who tested positive a day after landing (18). In another flight, 102 
medRxiv preprint doi: https://doi.org/10.1101/2021.01.11.21249626; this version posted January $13,2021$. The copyright holder for this preprint (which was not certified by peer review) is the author/funder, who has granted medRxiv a license to display the preprint in perpetuity.

It is made available under a CC-BY-NC 4.0 International license .

passengers traveled 4.66 hours from Tel Aviv, Israel to Frankfurt, Germany with 7 patients from a tourist group whom tested positive upon arrival. In this case, two in-air transmissions were possible, with both seated within 2 rows of an index case (19). Whether transmission occurred via large-droplets, contaminated surfaces, or aerosol inhalation is informed conjecture for these types of case studies. An ideal case study on an 18-hour Boeing 777 flight was completed in part thanks to the unique pre-testing, and quarantining required by New Zealand. During this flight, which included stops for refueling and in-flight meals, 4 in-flight transmission events occurred amongst 14 passengers located within 3 rows of an index case (20).

In this study, aerosol dispersion and deposition in two wide-body aircraft (Boeing a 767-300 and Boeing 777-200) was measured using fluorescent and DNA-tagged microspheres. Fluorescent 1 $\mu \mathrm{m}$ and DNA-tagged $3 \mu \mathrm{m}$ particles were released and measured in multiple rows and seats distributed throughout each aircraft. Experimental data included over 300 releases from a simulated SARS-CoV2-infected passenger in seats on 767-300 and 777-200 airframes in-flight, where extended exposure times are most likely. The tests were designed to measure the aerosol concentration within passenger breathing zones in neighboring seats and rows from the simulated infected passenger. The tests were also designed to measure passenger breathing zone aerosol concentration distributions at different sections of the airframes and with the simulated infected passenger seated at various locations, to determine if differences in exposure risk existed for different seats or rows of the aircraft. Additional testing, performed on the ground or at the terminal is the focus of follow-on studies (21).

\section{Materials and Methods}

\section{Airframe Testing}

Testing of each airframe totaled four days, with two days reserved for ground testing (not discussed here), and two days reserved for in-flight testing at altitude (typically 30,000+ feet). Only in-flight data is presented here, but data for all testing is being made available on Figshare (Supplement). Testing occurred at Dulles International Airport (IAD) with the first four days reserved for the Boeing 777, and the second four reserved for the Boeing 767.

Air exchange rates for the specific 767 and 777 airframes tested were reported to be 32 and 35 air changes per hour $(\mathrm{ACH})$, respectively, with total cabin volumes of 9320 and 15075 cubic feet. Both ECS systems achieve approximately $50 \%$ of the air exchange through HEPA-filtered recirculation, and $50 \%$ through fresh air.

Supplemental Figure 1 provides IBAC sensor layouts and release locations for each airframe and section tested. The sections were intended to distribute releases evenly throughout the airframe, with multiple sections in economy seating. These sections were named for their relative position in the airframe (Forward, Forward-Mid, Mid-Aft, and Aft on the 777 and Forward, Forward-Mid, and Aft on the shorter 767). Although a single release seat is marked, in all real-time fluorescent test cases multiple releases were completed at multiple seats in a row throughout each section. An overview of test days is described here, with specific dates, conditions, seat positions, and variables in supplemental tables S1-S8.

\section{7-200 Testing}

During the two days of in-flight testing, fluorescent tracer particles were released in the AFT, MIDAFT, FWD, and FWD-MID sections of the airframe for a total of 64 releases. The breathing releases included 40 tests with the mannequin not wearing a mask and 24 tests with a mask. Limited by the amount of test time available, multiple seats were prioritized over testing the mask at every seat, and up to three seats were tested per row. Seats included 47B, 47E 47K, 33B, 
medRxiv preprint doi: https://doi.org/10.1101/2021.01.11.21249626; this version posted January 13, 2021. The copyright holder for this preprint (which was not certified by peer review) is the author/funder, who has granted medRxiv a license to display the preprint in perpetuity.

It is made available under a CC-BY-NC 4.0 International license .

33E, 33K, 11A, 11G, 11L, 5A, 7A, 5G and 5L. Triplicate releases were performed for each mask on/off condition.

\section{7-300 Testing}

Fluorescent tracer particles released in the AFT, FWD-MID and FWD sections of the airframe for a total of 85 releases during two days of inflight testing. Specific seats included 37B, 37E, 37K, $18 \mathrm{~A}, 18 \mathrm{E}, 18 \mathrm{~L}, 6 \mathrm{~A}, 6 \mathrm{D}$, and $6 \mathrm{~L}$. Releases included mask and no-mask conditions, in triplicate. Throughout testing, the only technical issues were occasional loss of power to IBAC sensors due to loose connection to an airframe outlet or brief power cycling occurring with the airframe's electrical power.

\section{Chamber Characterization and Source Terms}

In an effort to better understand the tracer releases, four IBAC instruments and three TSI Inc. 3321 Aerodynamic Particle Sizers (APS) characterized the tracer releases with and without a mask in a characterized, controllable aerosol chamber. The chamber is a High Efficiency Particulate Air (HEPA)-filtered, rapidly-purged test chamber, where naturally-occurring background aerosols are minimized. During a test, the chamber was purged of particulate for two minutes, and then placed into a static mode without airflow. The test solution, which is a $10 \%$ dilution of the stock solution in deionized water, was nebulized identically to the airframe experiments and then briefly mixed using two remote-controllable fans (20-25 seconds).

The aerosol instrumentation characterized the resulting aerosol in particles per liter of air (pla) (Supplemental Figure 2). At 11902 liters, the average concentration across the aerosol detectors is multiplied by that total volume to give the amount of tracer particulate released and verify the size distribution (Supplemental Figure 3). The total number of particulate for each release condition has low standard error around the mean, with a total number of fluorescent tracers when unmasked of $1.8^{*} 10^{8}$, compared to $2.4^{*} 10^{7}$ beads for the larger $3 \mu \mathrm{m}$ DNA-tagged tracers (Table 2). The total number of particles released is essential for comparison with how much particulate enters the breathing zone of a given location.

The test sizes were chosen based on existing understanding of sizes most likely to contain SARS-CoV-2 virus. Liu, et al. sampled for RNA in Hospitals and found bimodal results in submicron $(0.25$ to $1 \mu \mathrm{m})$ and supermicron $(>2.5 \mu \mathrm{m})$ ranges (22). For comparison, a four-mode fit for typical breathing nose to mouth fit diameters at $0.8(86 \%), 1.8(9 \%), 3$. (3\%) and $5.5(2 \%)$ $\mu \mathrm{m}(23)$.

\section{Fluorescent Tracer Aerosol Detection}

A suite of Instantaneous Biological Analyzer and Collectors (IBAC, FLIR Systems), discrete particle detectors that simultaneously measures an airborne particle's elastic scatter and fluorescence at an excitation wavelength of $405 \mathrm{~nm}$, provided tracer detection and quantification. The IBAC contains two fluorescence thresholds, one for biological aerosols and the other for fluorescent tracer aerosol detection. IBAC sensors have been used for fluorescent tracer particle dispersion exposure testing and mapping in government, research, and clinical settings including subway systems, airports, skyscrapers, large building complexes, critical infrastructure facilities, commercial aircraft and numerous other types of buildings (24-27).

Fluoresbrite $1 \mu \mathrm{m}$ yellow-green (YG) polystyrene latex (PSL) microspheres (Polysciences), with a fluorescent signal distinct from naturally-occurring aerosols served as the test tracer. The comparatively fluorescent background particulate in a natural test environment, including airframes is negligible. During these tests, the background concentration was typically $<5$ pla, or 100 particles over a 6 minute integrated test. 
medRxiv preprint doi: https://doi.org/10.1101/2021.01.11.21249626; this version posted January $13,2021$. The copyright holder for this preprint (which was not certified by peer review) is the author/funder, who has granted medRxiv a license to display the preprint in perpetuity.

It is made available under a CC-BY-NC 4.0 International license .

The instrument samples at 3.5 liters per minute (lpm), and reports tracer counts per second. Prior to the airframe tests, the 42 IBACs were calibrated and the fluorescent particle tracer counts were matched to within an average variance of $\pm 10 \%$. IBAC sensors were setup to sample within the breathing zone (Supplemental Figure 4), situated in individual seats surrounding a test release.

Particulate penetration percentage was calculated as the number of particles observed in a given seat integrated over the release duration and return to background, normalized to a typical resting passenger minute volume $(7.5 \mathrm{lpm})$ rather than the instruments sampling rate of $3.5 \mathrm{lpm}$, and then divided by the total number of particles released based on the chamber characterization $\left(1.8^{\star} 10^{8}\right)$. This ratio represents the percentage of particulate, or mass for this mono-dispersed release, a person seated at rest near a source would likely inhale.

\section{DNA-Tagged Microspheres}

DNA-tagged tracers were streptavidin-coated $3 \mu \mathrm{m}$ PSL microspheres (Bangs Laboratories) bound with four unique 5'-biotynlated DNA oligos. Each oligo was designed to be 170 base pairs in length, non-coding and confirmed not to match natural sequences using a Basic Local Alignment Search Tool (BLAST) search (28). Complimentary quantitative real-time polymerase chain reaction (qRT-PCR) assays were designed for detection (IDT Inc.) targeting a $60^{\circ} \mathrm{C}$ extension and anneal step. Binding of biotinylated DNA occurred per the manufacturer's protocol, scaled to a $3 \mathrm{~mL}$ production volume, with the test particles washed five times via centrifugation at $10,000 \mathrm{rpm}$ to ensure removal of any unbound DNA.

Standard curves were developed for each bound oligo to quantify the number of beads, using a 40 cycle $95^{\circ} \mathrm{C}$ melt, and $60^{\circ} \mathrm{C}$ anneal and extension protocol on a QuantStudio 3 (ThermoFisher Inc). All samples were processed in triplicate, with dilutions of positive and negative controls in parallel, and each oligo used a uniform threshold for detection. No cycle threshold's (Ct) above background negative controls were accepted, and at least two of three replicates were required to be positive for analysis. This approach mimics PCR-based encapsulation of DNA-targets utilized by Harding, et al. for tracer experiments (29).

\section{Aerosol and Surface Collection}

DNA-tagged tracers were collected at 50 liters per minute using an Airport MD8 aerosol sampler (Sartorius), which operated for fifteen minutes, and collects $99.9995 \%$ of particles (30). Gel filters were extracted into $15 \mathrm{~mL}$ of deionized water, vortexed for 30 seconds, and diluted 1:10 in nanopure water for qPCR analysis. Five high volume air collectors were distributed near release rows and in the galley.

Surface coupons consisted of $8.89 \mathrm{~cm}$ long, $2.54 \mathrm{~cm}$ wide $(0.6 \mathrm{~mm}$ thick) stainless-steel rectangles held using painters tape, leaving a total area of $16.13 \mathrm{~cm}^{2}$ exposed during a release. These coupons were aseptically collected into $50 \mathrm{~mL}$ conical tubes, suspended using deionized water $(10 \mathrm{~mL})$, vortexed for 30 seconds, then utilized for qPCR. In between tests, areas were wiped using DNAaway and deionized water to remove any carryover. Coupon locations targeted common touch surfaces including arm rests, tables, and seatbacks (Supplemental Figure 5).

DNA-tagged beads were released in flight from three 767 locations (forward, mid-forward, and aft) and three 777 locations (forward, mid-forward, mid-aft), with surface coupons dispersed near the release seats, to look at fomite risk from a passenger due to aerosol surface deposition. Testing was completed in triplicate and averaged. Cycle thresholds converted into a number of beads per $\mathrm{mL}$ based on the qPCR standard curves. The concentration is transformed to a total number of beads based on the volume of the sample and the dilution. Comparing the number of beads collected at an aerosol collector to the total number released based on chamber 
medRxiv preprint doi: https://doi.org/10.1101/2021.01.11.21249626; this version posted January 13, 2021. The copyright holder for this preprint

(which was not certified by peer review) is the author/funder, who has granted medRxiv a license to display the preprint in perpetuity.

It is made available under a CC-BY-NC 4.0 International license.

characterization, gave a percentage of the total number of tracers that settled. In the case of surface samples, where the number of beads is per unit area, the percentage of beads captured at each location is scaled to a one square foot standard area.

\section{Nebulization \& Face Mask}

Either a Devilbiss Traveler (DNA-tagged tracer) or Devlibiss PulmoMate (fluorescent tracer) nebulizer provided aerosolization. DNA-tagged beads were generated for five minutes and fluorescent tagged microspheres were generated for one minute in a breathing pattern for 2 seconds on and 2 seconds off. The output of the nebulizer cup (Hudson Micro Mist) is plumbed through a tripod mounted mannequin head (Figure 5), and reaches a velocity of $1.43 \mathrm{~m} / \mathrm{s}$ at the mannequin's lips. The mannequin was used to allow for control of velocity of output air, to locate the release in the breathing zone, and to incorporate testing of a facemask.

Standard surgical 3-ply masks, which are the most likely to be handed out by an airline, were tested. A recent survey suggests that in the US, cloth masks were most commonly worn at least weekly by participants at $75 \%$, but surgical masks were next most common at $57 \%$ of participants engaging in weekly use, and are given out by airlines (31). 
medRxiv preprint doi: https://doi.org/10.1101/2021.01.11.21249626; this version posted January 13, 2021. The copyright holder for this preprint (which was not certified by peer review) is the author/funder, who has granted medRxiv a license to display the preprint in perpetuity.

It is made available under a CC-BY-NC 4.0 International license .

\section{Fluorescent Tracer Results 777}

Using the particle penetration percentage based on a $7.5 \mathrm{lpm}$ minute volume, the maximum exposure, $0.4614 \%$ occurs in a seat next to a source, and occurred during one release from seat 33B on the Boeing 777 (Table 1). The next two highest penetration percentages also occurred at this release location, and corresponded with $0.2577 \%$ and $0.3737 \%$. These were extreme outliers compared to all other releases on the 777 airframe. For a typical seat located immediately nearby a source, that is in front, behind, diagonally in front or behind, and two seats in front, behind, or left and right, the $95 \%$ confidence interval $(\mathrm{Cl})$ for mean particle penetration percentage was $0.0176 \%$ to $0.0348 \%$. Averaging across all sensors in the AFT and MID-AFT economy sections, the mean penetration percentage was $0.0124 \%$ and $0.0118 \%$.

Examining Figure 1, it is clear that although overall penetration percentages are low for nearby seats, and there are trends for seats adjacent, front, or behind a simulated infected passenger, it does depend on the release seat on the airframe (Figure 1A). The seats next to a release were naturally the highest, with the next highest typically occurring in the seats behind the simulated infected passenger. When grouping these releases in economy section of the 777 , there was a statistically significant difference between groups as determined by one-way ANOVA $(F(7,144)=$ $4.139, p=0.000$ ). Following that with a Tukey HSD post-hoc analysis and comparing with Figure $1 \mathrm{~A}$, indicates that the largest statistical differences are between the seats immediately next to the release point, which are statistically significant when compared to the diagonal front seats, front seats, and seats two away ( $p$-values of $0.000,0.023$, and 0.029 , respectively).

Notably, the differences between a seat in front, and diagonally in front, or rearward and diagonally rearward, are small, indicating that mixing within a row is occurring rapidly (Figure $1 \mathrm{~A}$ and $B$ ) Plotting the average penetration percentage across all sensors in a row, quantified the relative longitudinal flow forward or aftward depending on the release location. Figure $2 \mathrm{~A}$ shows that for both economy sections and release seats tested during 777 flights, contaminants mix towards the aft of the plane, where the outflow valve is located.

First class seats do not have the same arrangement, with nearby passengers inherently more spread out. The maximum exposure percentage $(0.0614 \%)$ in the forward and fwd-mid (rows 5 and 11 , respectively) occurred in a seat (12A) immediately behind the release location (11A). The 95\% confidence interval for the mean exposure risk for those same closest seats on this airframe ranges from 0.0120 to $0.0150 \%$. Amongst all of the sensors spread out throughout the section, the average exposure risk for the fwd-mid by penetration percentage was $0.0026 \%$ and for the forward section, $0.0034 \%$ (Table 1 ).

\section{7}

The maximum exposure risk of the Boeing 767 was lower than the 777 , measured at a penetration percentage of $0.0947 \%$. The highest risk was measured in a seat $(18 \mathrm{~A})$ located immediately adjacent to a release location for an infected passenger (18B), with the next highest penetration percentage also measured in seat $18 \mathrm{~A}$, at $0.0791 \%$. However, when averaging those seats closest to an infected passenger, two seats away (front, back and to the side) and one seat diagonally, the $95 \% \mathrm{Cl}$ for the mean penetration percentage was from 0.0148 to $0.0205 \%$ (Table 1). For the 767 in-flight tests, the seats closest to the release remained the most at risk for inhalation, but there were no extreme outliers, and the importance of the specific release seat on the airframe becomes apparent (Figure 1B). Again, the rapid mixing, and high air exchange rate led to seats diagonally located away from the release to behave similarly as those immediately in front of the release, and those located behind the release to behave similarly to those located diagonally behind (Figure 1B and $\mathrm{C}$ ). When averaging penetration efficiency amongst every seat 
medRxiv preprint doi: https://doi.org/10.1101/2021.01.11.21249626; this version posted January $13,2021$. The copyright holder for this preprint (which was not certified by peer review) is the author/funder, who has granted medRxiv a license to display the preprint in perpetuity.

It is made available under a CC-BY-NC 4.0 International license .

with a sensor in the section, the mean penetration efficiency decreases to 0.0088 and $0.0086 \%$ for the aft and fwd-mid sections of the airframe.

In the 767 , combining release location data to examine nearby seat relationships leads to expanded box and whisker plots (Figure 1C). The corresponding ANOVA concluded that there is a statistically significant difference between groups $(F(7,169)=2.718, p=0.011$, alpha $=0.05)$, but the post-hoc Tukey HSD, determined that the statistical significance is limited to seats located to the side of a release, and those located two seats away. Judging from the individual seat release comparisons, there is further variance based on the location within the plane (Figure 1B) when compared to the 777 (Figure 1A).

Comparing the longitudinal flow for the 767 , there is less aftward flow of contamination. The aft release seats in row 37 primarily mix towards the aft of the airframe, but the fwd-mid releases in row 18 primarily mix forward (Figure $2 \mathrm{~B}$ ).

First Class Seats in the Boeing 767 experienced lower maximum and average penetration percentages, with the two maximums, 0.0337 and $0.0305 \%$, occurring in seat $7 \mathrm{~A}$, diagonally behind the release seat $6 \mathrm{D}$. The $95 \% \mathrm{Cl}$ for the mean exposure risk in the nearby seats ranged from 0.0099 to $0.0139 \%$, but importantly, there were no IBAC sensors directly next to any of the release locations in this forward first class section. Amongst all nearby sensors in the forward section, the average was $0.0047 \%$ (Table 1 ).

\section{Effect of Mannequin Mask}

The efficacy of the standard 3-ply mask was not the primary goal of this testing as the variety of droplet sizes and velocities at the mouth vary at the mouth/mask interface, especially as a function of whether they are generated via talking, breathing, coughing, or sneezing. This group of tests was rather to determine if redirecting air at lower breathing velocities with a facemask in place made a difference in the number of particles reaching the breathing zone of nearby passengers. Existing literature visualizing droplet and jet production with a mask found leakage and redirection of jets and particulate upwards, downwards, and to the sides of the mask $(32,33)$.

For each set of tests with and without a mask in the same seat, there is a statistically significant difference between tests from the same seat with and without a mask ( $p=0.045$, alpha 0.05), when using a paired student's t-test. The average reduction with a mask in total particles counted at all sensors was $15.6 \%$, compared with a mean reduction of $7.6 \%$ in the static characterization chamber. There was a large standard deviation, leading to an increase in total particle counts at times, with a maximum increase (negative decrease) of $26.6 \%$ and a total of 3 of the 14 release seats showing an increase ( 767 seats $18 \mathrm{~L}$ and $18 \mathrm{E}, 777$ seat $33 \mathrm{E}$ ) in total counted particles in the breathing zone.

As further evidence of masks redirecting particles, of the 11 source locations with total particle count decreases, 9 sensors on average observed an increase in particle count, with 27 observing a decrease.

\section{DNA-Tagged Results - 777 Inflight}

DNA-tagged microspheres demonstrate clear trends similar to real-time data. In the case of air samples, the collected fraction of particles aerosolized compares well with the real-time fluorescent tracer, ranging from undetectable to $0.030 \%$ in economy sections closest to the release point (Figure $3 \mathrm{~A}$ ). The highest collected aerosol concentration was always located closest to the release point of that DNA-tagged bead, with lower risks forward of a release than aft of the release. A low concentration of tracer particles were present in the aft galley from the economy 
medRxiv preprint doi: https://doi.org/10.1101/2021.01.11.21249626; this version posted January $13,2021$. The copyright holder for this preprint (which was not certified by peer review) is the author/funder, who has granted medRxiv a license to display the preprint in perpetuity.

It is made available under a CC-BY-NC 4.0 International license .

release, and the aftward movement of contaminant seen in the fluorescent particulate data is duplicated here.

Surface samples located on the arm rests and seat backs of the seats closest to each release location were scaled from their size to a standard square foot for better comparison. Even scaling to a larger surface area, less than $0.03 \%$ of tracer particles settle out during testing, with the highest concentration on the surfaces closest to each release location. Notably horizontal surfaces, such as arm rests were typically higher than vertical surfaces such as seatbacks and inflight entertainment (IFE) systems. The low overall deposition leads to higher $95 \% \mathrm{Cl}$ (Supplemental Table 9).

\section{DNA-Tagged Results - 767 Inflight}

The DNA-tagged tracer releases completed on the 777 were duplicated on the 767 , with surface samples targeted at high-touch surfaces. Similar to the 777 , air samplers agreed with the fluorescent real-time releases, with the highest number of particles nearest each release location, and the overall percentage of particles compared to the chamber characterization consistently below $0.02 \%$ located 3 rows away (Figure $3 \mathrm{~B}$ ).

The percentage of particles that settled onto contaminated surfaces, scaled to a standard square foot, remains low with a maximum deposition percentage less than $0.005 \%$. Arm rests and table tops closest to the release location consistently had the highest level of contamination for each release location. Confidence intervals are large for surface samples due to low overall deposition and signal (Supplemental Table 10).

\section{Discussion}

Overall, rapid mixing, dilution and removal limit exposure risk for aerosol contaminants at 1 and 3 $\mu \mathrm{m}$ in all tested seat sections of the Boeing 767 and Boeing 777 wide body aircraft. The maximum exposure in a nearby seat of $0.4614 \%$ of a characterized release, equates to a $99.54 \%$ reduction from an aerosolized source of contamination such as SARS-CoV-2. Looking further across the approximately 40 seats nearby the simulated infected patient there is average reduction maximum in the aft section of the 777 , with exposure risk of $0.0124 \%$, representing a $99.99 \%$ reduction. Importantly, this represents a single infectious point source, not a scenario with multiple infected passengers. Testing focused on aerosol transport and smaller 1 to $3 \mu \mathrm{m}$ particulate. Larger droplets (10s to 100 s of microns) generated and co-released with smaller modes when talking, coughing, or sneezing introduce an alternative transmission mechanism, which face masks have been shown to statistically reduce in other literature $(34,35)$.

These data support the findings of epidemiologic studies of commercial airframe transmission for passengers with SARS-CoV-2, especially those that were unlikely to be exposed in other circumstances. Freedman \& Wilder-Smith reviewed all known studies of passenger air travel with COVID-positive passengers that studied potential secondary cases (36). Conclusions included a summary of 8 mass transmission flights, typically with many primary cases, and 58 cases with zero transmission. In another epidemiological study, 102 passengers traveled 4.66 hours from Tel Aviv, Israel to Frankfurt, Germany with 7 patients from a tourist group who tested positive upon arrival. In this case, two in-air transmissions were probably, with both seated within 2 rows of an index case (19).

This data similarly does not focus on contamination of surfaces via non-aerosol routes (via large droplets or fecal contamination), which is likely more common in areas such as the lavatory. Alternative routes of exposure are more challenging to predict because of uncertainty in human behavior (37). Testing did not include movement of passengers throughout the plane, and the mannequin remained facing forward. Testing was also limited to two particles sizes, and three to 
medRxiv preprint doi: https://doi.org/10.1101/2021.01.11.21249626; this version posted January 13, 2021. The copyright holder for this preprint (which was not certified by peer review) is the author/funder, who has granted medRxiv a license to display the preprint in perpetuity.

It is made available under a CC-BY-NC 4.0 International license .

four rows of each aircraft. Conclusions outside of specifically tested seats and breathing zones assumes extrapolation of the data to new conditions.

Widespread aerosol exposure risk is minimal during long duration flights, but still present, and is notably highest in the row of an index patient. Rows in front and behind the index patient have the next highest risk on average. While there is a measurable difference in middle vs aisle or window seat, exposure risk does depend on location and seat throughout the airframe.

\section{Acknowledgments}

We would like to thank United States Transportation Command (USTRANSCOM) for their sponsorship of this work, as well as the technical direction and assistance of the Defense Advanced Research Projects Agency (DARPA). The team would also like to acknowledge United Airlines for their donation of time, access, and expertise, including physical use of two airframes, access to a terminal jetway, crew, support for inflight testing, and engineering and technician support for electrical and ECS system performance. Importantly, Boeing engineers answered significant questions about expected ECS system behavior and design, including providing air exchange and volume measurements. A special thanks also belongs to Zeteo Tech Inc, especially Wayne Bryden and Mike McLoughlin, for their technical and programmatic assistance with aerosol testing. L2 Defense and Russel Accardi helped facilitate loaning of detection instrumentation for experimentation.

\section{References}

1. S. McMahon, TSA recorded America's busiest travel day since March over Labor Day weekend. Washington Post (2020).

2. CDC, "SARS-CoV-2 \& Potential Airborne Transmission" (2020). Scientific Brief. < https://www.cdc.gov/coronavirus/2019-ncov/more/scientific-brief-sars-cov-2.html>

3. J. A. Lednicky, et al., Viable SARS-CoV-2 in the air of a hospital room with COVID-19 patients. medRxiv, 2020.08.03.20167395 (2020).

4. J. L. Santarpia, et al., Aerosol and surface contamination of SARS-CoV-2 observed in quarantine and isolation care. Sci. Rep. 10, 1-8 (2020).

5. F. W. Moses, R. Gonzalez-Rothi, G. Schmidt, COVID-19 Outbreak associated with air conditioning in restaurant, Guangzhou, China, 2020. Emerg. Infect. Dis. 26, 2298 (2020).

6. Hamner, et al., High SARS-CoV-2 Attack Rate Following Exposure at a Choir Practice. Morb. Mortal. Wkly. Rep. High 69, 606-610 (2020).

7. P. de Man, et al., Outbreak of COVID-19 in a nursing home associated with aerosol transmission as a result of inadequate ventilation. Clin. Infect. Dis. (2020) https:/doi.org/10.1093/cid/ciaa1270.

8. Z. Zhang, X. Chen, S. Mazumdar, T. Zhang, Q. Chen, Experimental and numerical investigation of airflow and contaminant transport in an airliner cabin mockup. Build. Environ. 44, 85-94 (2009).

9. B. Li, et al., Experimental studies of thermal environment and contaminant transport in a commercial aircraft cabin with gaspers on. Indoor Air 26, 806-819 (2016).

10. W. Yan, Y. Zhang, Y. Sun, D. Li, Experimental and CFD study of unsteady airborne pollutant transport within an aircraft cabin mock-up. Build. Environ. 44, 34-43 (2009).

11. G. N. Sze To, M. P. Wan, C. Y. H. Chao, L. Fang, A. Melikov, Experimental study of dispersion and deposition of expiratory aerosols in aircraft cabins and impact on infectious disease transmission. Aerosol Sci. Technol. 43, 466-485 (2009).

12. M. P. Wan, et al., Modeling the fate of expiratory aerosols and the associated infection risk in an aircraft cabin environment. Aerosol Sci. Technol. 43, 322-343 (2009). 
13. R. You, et al., Predicting airflow distribution and contaminant transport in aircraft cabins with a simplified gasper model. J. Build. Perform. Simul. 9, 699-708 (2016).

14. Y. Sun, Y. Zhang, A. Wang, J. L. Topmiller, J. S. Bennet, Experimental characterization of airflows in aircraft cabins, Part I: Experimental system and measurement procedure. ASHRAE Trans. 111 PART 2, 45-52 (2005).

15. J. S. Bennett, et al., Airborne exposure patterns from a passenger source in aircraft cabins. HVAC R Res. 19, 962-973 (2013).

16. F. Li, J. Liu, J. Pei, C. H. Lin, Q. Chen, Experimental study of gaseous and particulate contaminants distribution in an aircraft cabin. Atmos. Environ. 85, 223-233 (2014).

17. S. J. Olsen, et al., Transmission of the Severe Acute Respiratory Syndrome on Aircraft. N. Engl. J. Med. 349, 2416-2422 (2003).

18. K. L. Schwartz, et al., Lack of COVID-19 transmission on an international flight. Cmaj 192, E410 (2020).

19. S. Hoehl, et al., Assessment of SARS-CoV-2 Transmission on an International Flight and Among a Tourist Group. JAMA Netw. open 3, e2018044 (2020).

20. T. Swadi, et al., A case study of extended in-flight transmission of SARS-CoV-2 en route to Aotearoa New Zealand. 1-12 Preprint. <https://doi.org/10.26091/ESRNZ.13257914.v1 (December 12, 2020).

21. D. Silcott, et al., "TRANSCOM/AMC Commercial Aircraft Cabin Aerosol Dispersion Tests" (2020). <https://www.ustranscom.mil/cmd/docs/TRANSCOM\%20Report\%20Final.pdf>

22. Y. Liu, et al., Aerodynamic analysis of SARS-CoV-2 in two Wuhan hospitals. Nature 582, 557-560 (2020).

23. L. Morawska, et al., Size distribution and sites of origin of droplets expelled from the human respiratory tract during expiratory activities. J. Aerosol Sci. 40, 256-269 (2009).

24. R. DeFreez, LIF bio-aerosol threat triggers: then and now. Opt. Based Biol. Chem. Detect. Def. V7484, 74840H (2009).

25. J. C. Liljegren, D. F. Brown, M. M. Lunden, D. Silcott, Particle deposition onto people in a transit venue. Heal. Secur. 14, 237-249 (2016).

26. J. Therkorn, et al., Impact of air-handling system exhaust failure on dissemination pattern of simulant pathogen particles in a clinical biocontainment unit. Indoor Air 29, 143-155 (2019).

27. N. R. de Sousa, L. Shen, D. Silcott, C. J. Call, A. G. Rothfuchs, Operative and technical modifications to the Coriolis $\AA \mu$ air sampler that improve sample recovery and biosafety during microbiological air sampling. bioRxiv, 2020.02.11.943662 (May 29, 2020).

28. S. F. Altschul, W. Gish, W. Miller, E. W. Myers, D. J. Lipman, Basic local alignment search tool. J. Mol. Biol. 215, 403-410 (1990).

29. R. N. Harding, et al., Unique DNA-barcoded aerosol test particles for studying aerosol transport. Aerosol Sci. Technol. 50, 429-435 (2016).

30. S. R. Parks, An assessment of the Sartorius MD8 microbiological air sampler. J. Appl. Bacteriol. 80, 529-534 (1996).

31. M. \& Company, "Survey: In the US, people say their use of masks may endure" (2020). $<$ https://www.mckinsey.com/featured-insights/americas/survey-in-the-us-people-saytheir-use-of-masks-may-endure >

32. J. W. Tang, T. J. Liebner, B. A. Craven, G. S. Settles, A schlieren optical study of the human cough with and without wearing masks for aerosol infection control. J. R. Soc. Interface 6, 727-736 (2009).

33. V. Arumuru, J. Pasa, S. S. Samantaray, Experimental visualization of sneezing and efficacy of face masks and shields. Phys. Fluids 32 (2020).

34. N. H. L. Leung, et al., Respiratory virus shedding in exhaled breath and efficacy of face masks. Nat. Med. 26 (2020). 
medRxiv preprint doi: https://doi.org/10.1101/2021.01.11.21249626; this version posted January 13, 2021. The copyright holder for this preprint

(which was not certified by peer review) is the author/funder, who has granted medRxiv a license to display the preprint in perpetuity.

It is made available under a CC-BY-NC 4.0 International license.

35. C. R. Macintyre, A. Ahmad, International Journal of Nursing Studies A rapid systematic review of the efficacy of face masks and respirators against coronaviruses and other respiratory transmissible viruses for the community, healthcare workers and sick patients. Int. J. Nurs. Stud. 108, 103629 (2020).

36. D. O. Freedman, A. Wilder-Smith, In-flight transmission of SARS-CoV-2: a review of the attack rates and available data on the efficacy of face masks. J. Travel Med. (2020) https:/doi.org/10.1093/jtm/taaa178.

37. S. H. Bae, et al., Asymptomatic Transmission of SARS-CoV-2 on Evacuation Flight. Emerg. Infect. Dis. J. 26 (2020). 
medRxiv preprint doi: https://doi.org/10.1101/2021.01.11.21249626; this version posted January 13, 2021. The copyright holder for this preprint (which was not certified by peer review) is the author/funder, who has granted medRxiv a license to display the preprint in perpetuity.

It is made available under a CC-BY-NC 4.0 International license .

Penetration Percentages for Nearby Seating (777 \& 767) with and without a Mask in Economy Compared to First Class

Economy First Class

Breathing Breathing Breathing w/o Mask w/Mask w/o Mask

\begin{tabular}{|c|c|c|c|c|c|c|}
\hline & & & Sample Size $(n)$ & 177 & 172 & 54 \\
\hline & & & 95.0\% Lower CL for Mean & $0.0148 \%$ & $0.0133 \%$ & $0.0099 \%$ \\
\hline & & & Mean & $0.0176 \%$ & $0.0158 \%$ & $0.0119 \%$ \\
\hline & & & 95.0\% Upper CL for Mean & $0.0205 \%$ & $0.0183 \%$ & $0.0139 \%$ \\
\hline & 767 & Percentage & Standard Deviation & $0.0190 \%$ & $0.0165 \%$ & $0.0074 \%$ \\
\hline & & & Standard Error of Mean & $0.0014 \%$ & $0.0013 \%$ & $0.0010 \%$ \\
\hline & & & Minimum & $0.0000 \%$ & $0.0000 \%$ & $0.0023 \%$ \\
\hline & & & Median & $0.0127 \%$ & $0.0107 \%$ & $0.0110 \%$ \\
\hline & & & Maximum & $0.0947 \%$ & $0.0796 \%$ & $0.0337 \%$ \\
\hline & & & Sample Size (n) & 152 & 120 & 102 \\
\hline & & & 95.0\% Lower CL for Mean & $0.0176 \%$ & $0.0120 \%$ & $0.0120 \%$ \\
\hline & & & Mean & $0.0262 \%$ & $0.0160 \%$ & $0.0150 \%$ \\
\hline & & & 95.0\% Upper CL for Mean & $0.0348 \%$ & $0.0201 \%$ & $0.0180 \%$ \\
\hline & 777 & Percentage & Standard Deviation & $0.0538 \%$ & $0.0223 \%$ & $0.0153 \%$ \\
\hline & & & Standard Error of Mean & $0.0044 \%$ & $0.0020 \%$ & $0.0015 \%$ \\
\hline & & & Minimum & $0.0000 \%$ & $0.0000 \%$ & $0.0000 \%$ \\
\hline & & & Median & $0.0154 \%$ & $0.0081 \%$ & $0.0094 \%$ \\
\hline & & & Maximum & $0.4614 \%$ & $0.1157 \%$ & $0.0614 \%$ \\
\hline
\end{tabular}

Table 1. Economy (with and without a mask) and first class penetration percentages for nearby seats on the Boeing 767 and 777 . Nearby seats are defined as within 2 seats left, right, front and back, and the four diagonal seats. 


\begin{tabular}{|c|c|c|c|}
\hline & & Statistic & Result \\
\hline \multirow{9}{*}{ 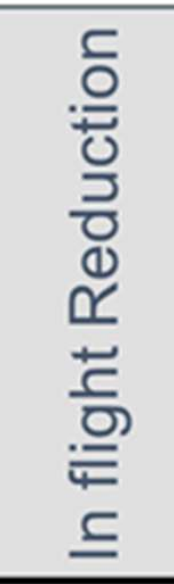 } & \multirow{9}{*}{ 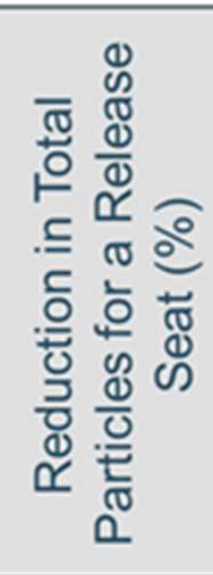 } & Sample Size (n) & 14 \\
\hline & & 95.0\% Lower CL for Mean & $3.5 \%$ \\
\hline & & Mean & $15.6 \%$ \\
\hline & & 95.0\% Upper CL for Mean & $27.7 \%$ \\
\hline & & Standard Deviation & $20.9 \%$ \\
\hline & & Standard Error of Mean & $5.6 \%$ \\
\hline & & Minimum & 6 \\
\hline & & Median & $17.7 \%$ \\
\hline & & Maximum & $52.3 \%$ \\
\hline \multirow{12}{*}{ 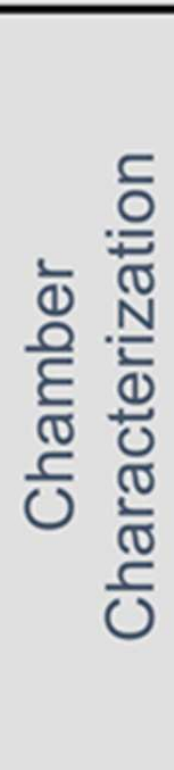 } & \multirow{4}{*}{ 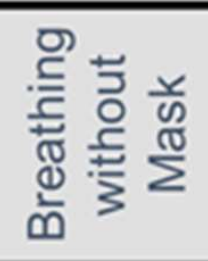 } & Sample Size (n) & 3 \\
\hline & & Mean (Total Particles) & $1.8 E+08$ \\
\hline & & Standard Deviation & 1.7E+07 \\
\hline & & Standard Error of Mean & $1.0 \mathrm{E}+07$ \\
\hline & \multirow{4}{*}{ 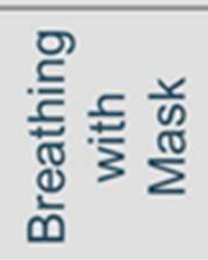 } & Sample Size $(n)$ & 3 \\
\hline & & Mean (Total Particles) & 1.7E+08 \\
\hline & & Standard Deviation & $8.5 E+06$ \\
\hline & & Standard Error of Mean & $4.9 E+06$ \\
\hline & \multirow{4}{*}{ 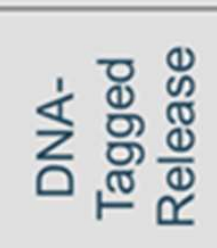 } & Sample Size (n) & 3 \\
\hline & & Mean (Total Particles) & $2.4 \mathrm{E}+07$ \\
\hline & & Standard Deviation & $4.3 E+06$ \\
\hline & & Standard Error of Mean & $2.5 E+06$ \\
\hline
\end{tabular}

Table 2. The effect of mask wearing during inflight testing and in an aerosol chamber. Top is the percent reduction in total counted particles for each release seat in triplicate with and without a mask. Bottom represents the aerosol chamber characterization for each tracer release, including total particles with and without a mask. 
medRxiv preprint doi: https://doi.org/10.1101/2021.01.11.21249626; this version posted January 13, 2021. The copyright holder for this preprint (which was not certified by peer review) is the author/funder, who has granted medRxiv a license to display the preprint in perpetuity.

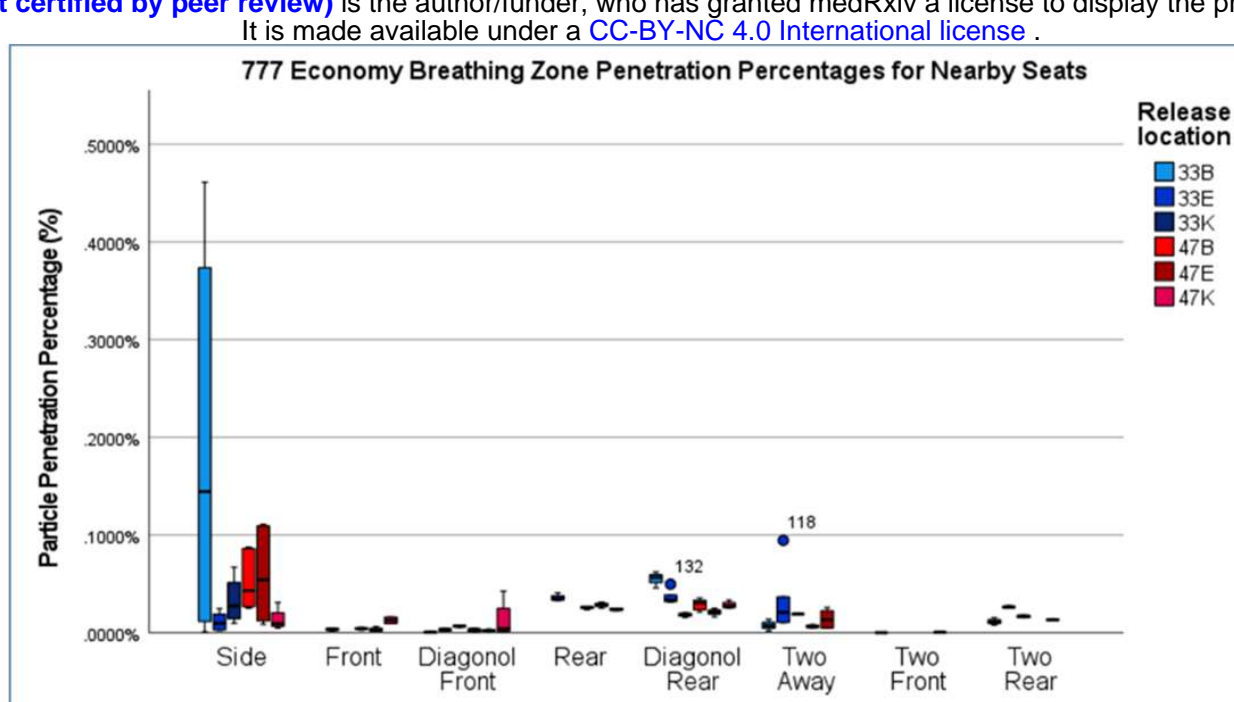

A

Nearby Seats

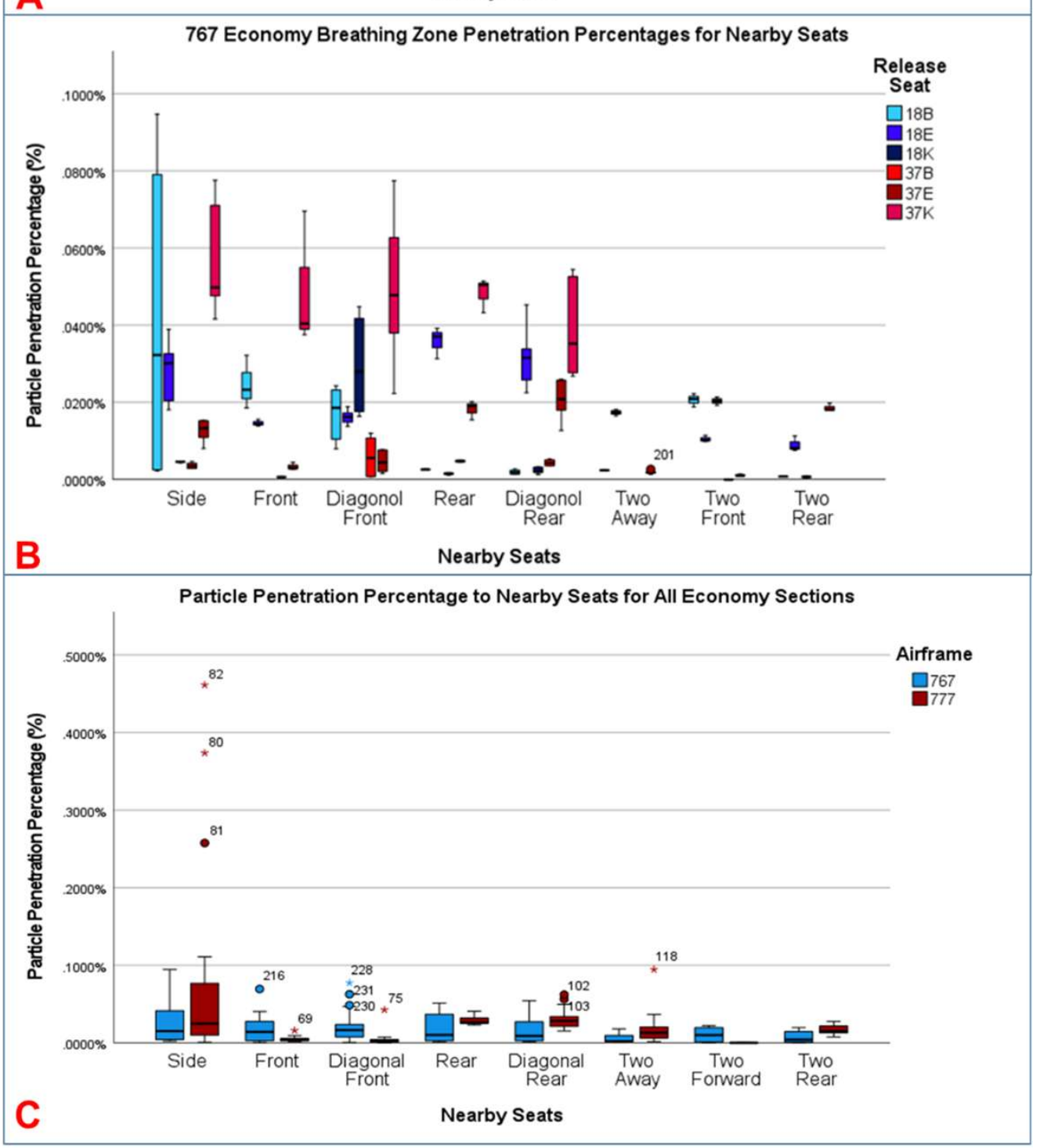

Figure 1. Particle penetration percentages for various 777 and 767 seat configurations. A) Penetration percentages for unmasked breathing in seats near an economy source throughout an economy section of a Boeing 777. B) Penetration percentages for unmasked breathing releases throughout an economy section of a Boeing 767. C) Penetration percentages for releases throughout an economy section of a Boeing 777 compared to a 767 . The 777 side seats have three outliers not presented in C) representing the maximum exposure for all experiments $(0.2577,0.3737$, and $0.4614 \%)$. 


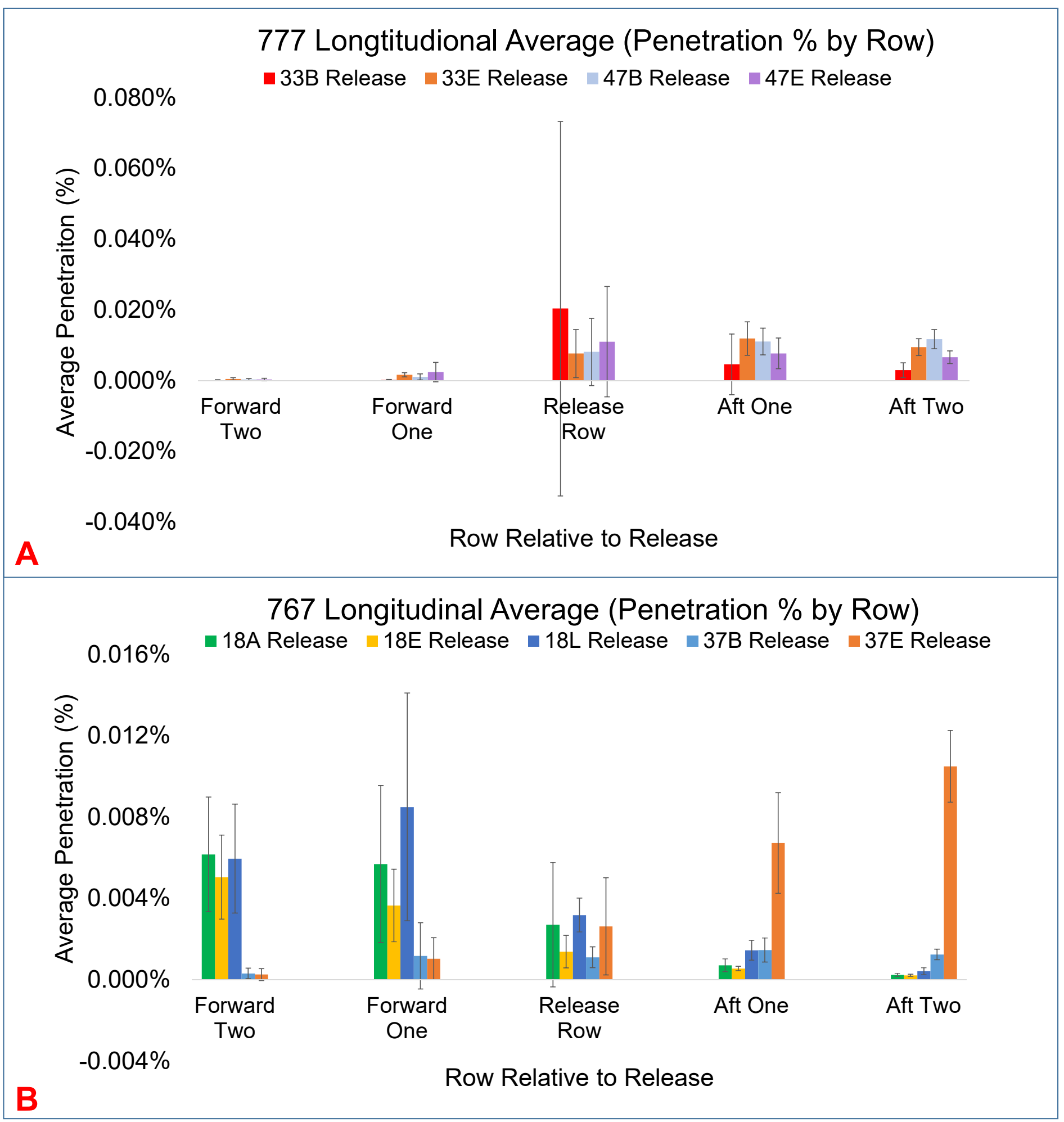

Figure 2. Comparison of longitudinal movement of particles forward and aft of the release row. A) 777-200 longitudinal average penetration percentage (error bars represent one standard deviation) across all sensors in a given row. For the 777 there is a clear aft movement of contaminant from both row 33 and row 47 . The release row contains the highest uncertainty, as seats next to the release point are averaged with sensors much further in the same row. B) 767-300 longitudinal average penetration percentage For the 767 forward releases from row 18 mix more forward, for aft releases, contamination mixes towards the outflow valve in the rear of the airframe. 
medRxiv preprint doi: https://doi.org/10.1101/2021.01.11.21249626; this version posted January 13, 2021. The copyright holder for this preprint (which was not certified by peer review) is the author/funder, who has granted medRxiv a license to display the preprint in perpetuity. It is made available under a CC-BY-NC 4.0 International license.

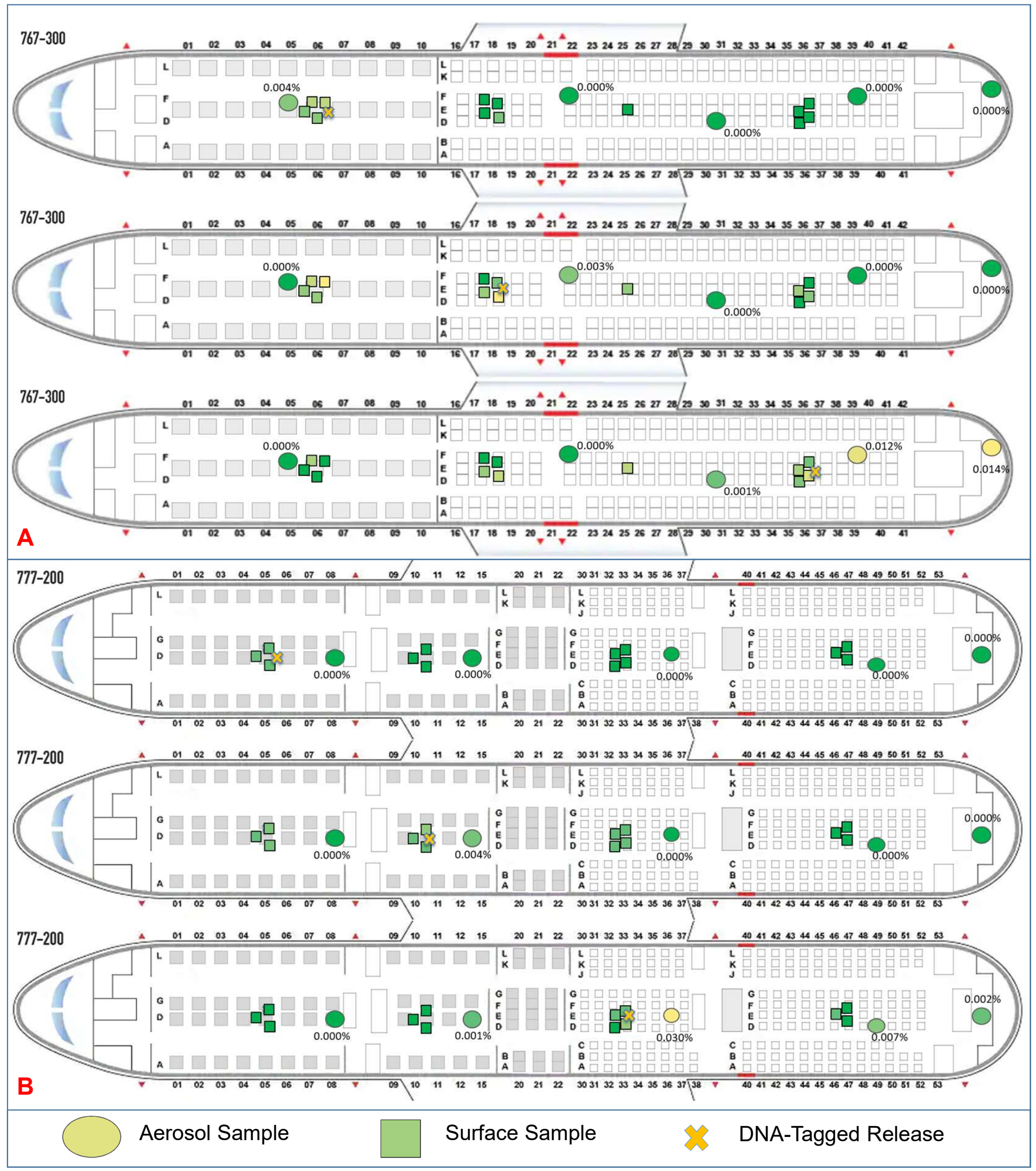

Figure 3. DNA-tagged tracer maps. A) 777-200 DNA-tagged tracer particle maps for fwd, fwdmid, and mid-aft releases. B) 767-300 DNA-tagged tracer particle maps for fwd, fwd-mid, and aft releases. Surface contamination is minimal, and aerosol collections are similar to real-time fluorescent results. Circles represent aerosol samples, with squares representing surface samples. Colors are assigned solely for relative comparison purposes. 